NANCY H. TEETERS

Brookings Institution

\title{
Budgetary Outlook at Mid-Year 1970
}

The FeDeral BUDGeTARY POSITION has exhibited over the past two years the most dramatic shifts in the postwar period. The budget calculated at full employment swung from a deficit of $\$ 13 \frac{1}{2}$ billion in mid-1968 to a surplus of $\$ 101 / 2$ billion in mid-1969 and returned to a minor deficit by mid-1970, as shown in Table 1. If the administration is able to hold total expenditures to levels discussed last spring, the budgetary position would again be reversed and a full employment surplus of $\$ 16$ billion would be in evidence by mid-1971. A number of proposals currently being considered in Congress would, however, make realization of the official estimates not only difficult, but probably impossible.

\section{New Estimates for 1971}

On May 19, the administration released official revisions of the 1971 budget. Expenditures were revised upward by $\$ 4.8$ billion (unified basis) from $\$ 200.8$ billion to $\$ 205.6$ billion. Of the increase, $\$ 2.3$ billion was for increased outlays in the "uncontrollable" programs- $\$ 1$ billion for interest, $\$ 500$ million for unemployment benefits, and the rest for medicare, medicaid, farm price supports, and so on. Of the remaining $\$ 2.5$ billion, $\$ 1.4$ billion reflects the early enactment of the federal pay increase; and $\$ 500$ million the presidential lifting of the freeze on construction. The remaining $\$ 600$ million is the net result of $\$ 1.9$ billion in increased expenditures in 


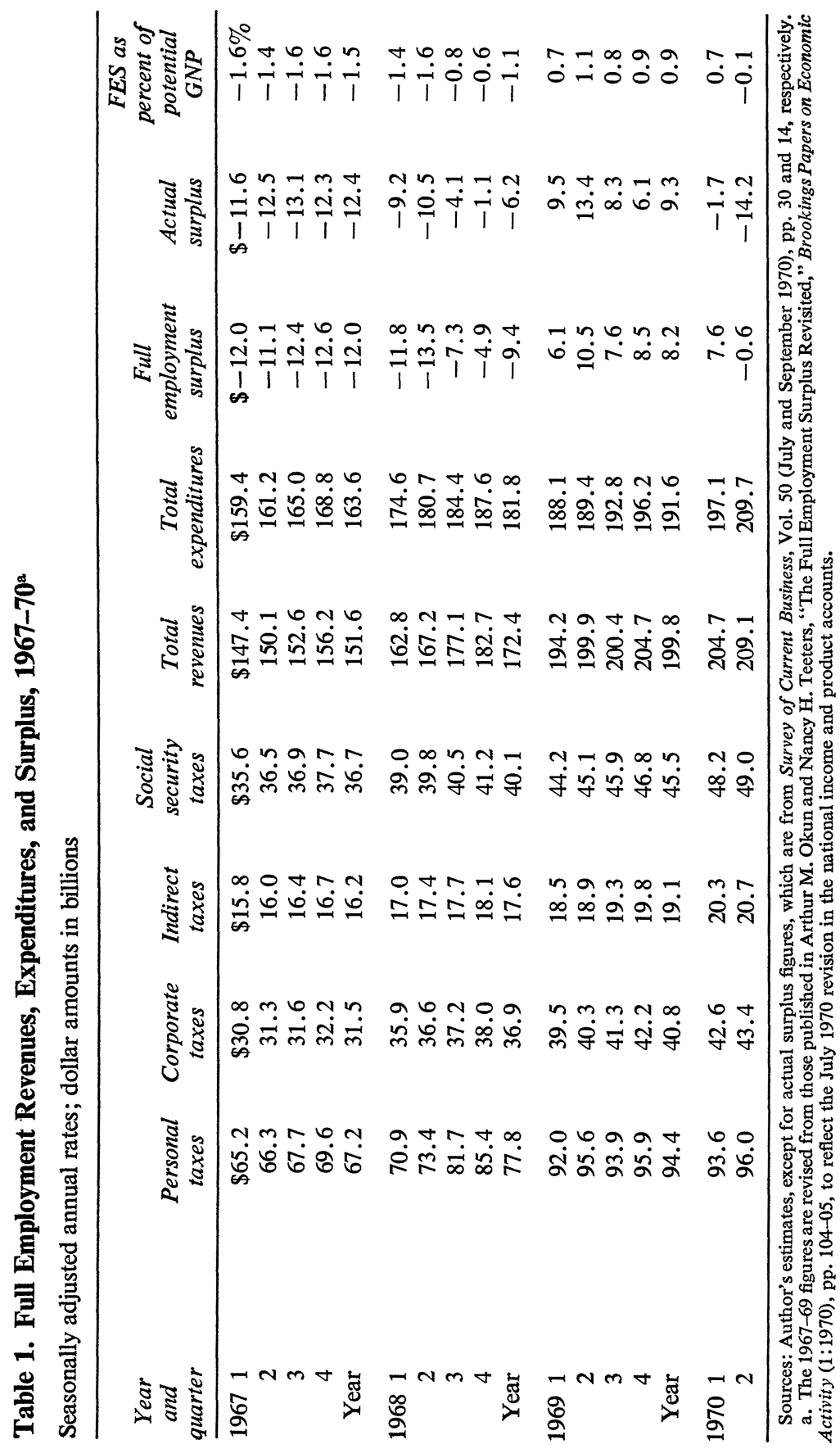


some programs offset by $\$ 1.3$ billion in decreases in others. Most of the decreases appear likely to be achieved.

In testimony in July before the Joint Economic Committee, the director of the Office of Management and Budget (OMB) put the uncontrollables at $\$ 3.5$ billion above the original estimates, an increase of $\$ 1.2$ billion since May.

On the revenue side, the February estimates of \$202.1 billion, based on a gross national product (GNP) of $\$ 985$ billion, were revised downward in May by $\$ 900$ million; a $\$ 1.5$ billion reduction in corporate and individual tax revenues was partially offset by small increases in revenue from other sources. In addition, the administration asked for a tax on the lead used in gasoline ( $\$ 1.6$ billion), and for an acceleration of the collection of estate and gift taxes ( $\$ 1.5$ billion). As a result of these changes, the official estimates of the 1971 budget shifted from a $\$ 1.3$ billion surplus to a $\$ 1.3$ billion deficit.

Using the July revision of estimates of the uncontrollables, the administration's proposed budget for fiscal 1971 is shown in Table 2.

Table 2. February, May, and July 1970 Estimates of the Unified Budget, Fiscal Year 1971

Billions of dollars

\begin{tabular}{|c|c|c|c|c|c|}
\hline Budget item & $\begin{array}{l}\text { January } \\
\text { estimate }\end{array}$ & Change & $\begin{array}{c}\text { May } \\
\text { estimate }\end{array}$ & Change & $\begin{array}{l}\text { Implicit } \\
\text { July } \\
\text { estimate }\end{array}$ \\
\hline Receipts & 202.1 & +2.2 & 204.3 & 0.0 & 204.3 \\
\hline Outlays & 200.8 & +4.8 & 205.6 & +1.2 & 206.8 \\
\hline Budget surplus or deficit & +1.3 & -2.6 & -1.3 & -1.2 & -2.5 \\
\hline
\end{tabular}

Table 3 shows the July estimates translated into the federal sector of the national income accounts (NIA) adjusted to a full employment basis, and the estimated phasing of those expenditures by half-years through fiscal year 1971. In the last half of calendar 1969, the federal sector had a full employment surplus of $\$ 8$ billion (annual rate), very close to the actual surplus of $\$ 7.2$ billion. The combination of rising expenditures and tax rate reductions shifted the full employment surplus to $\$ 31 / 2$ billion during the first half of 1970; reflecting this shift and the economic slowdown, the budget had an actual deficit rate of $\$ 8.0$ billion in that period. Under the administration's proposals, the full employment surplus would rise mod- 


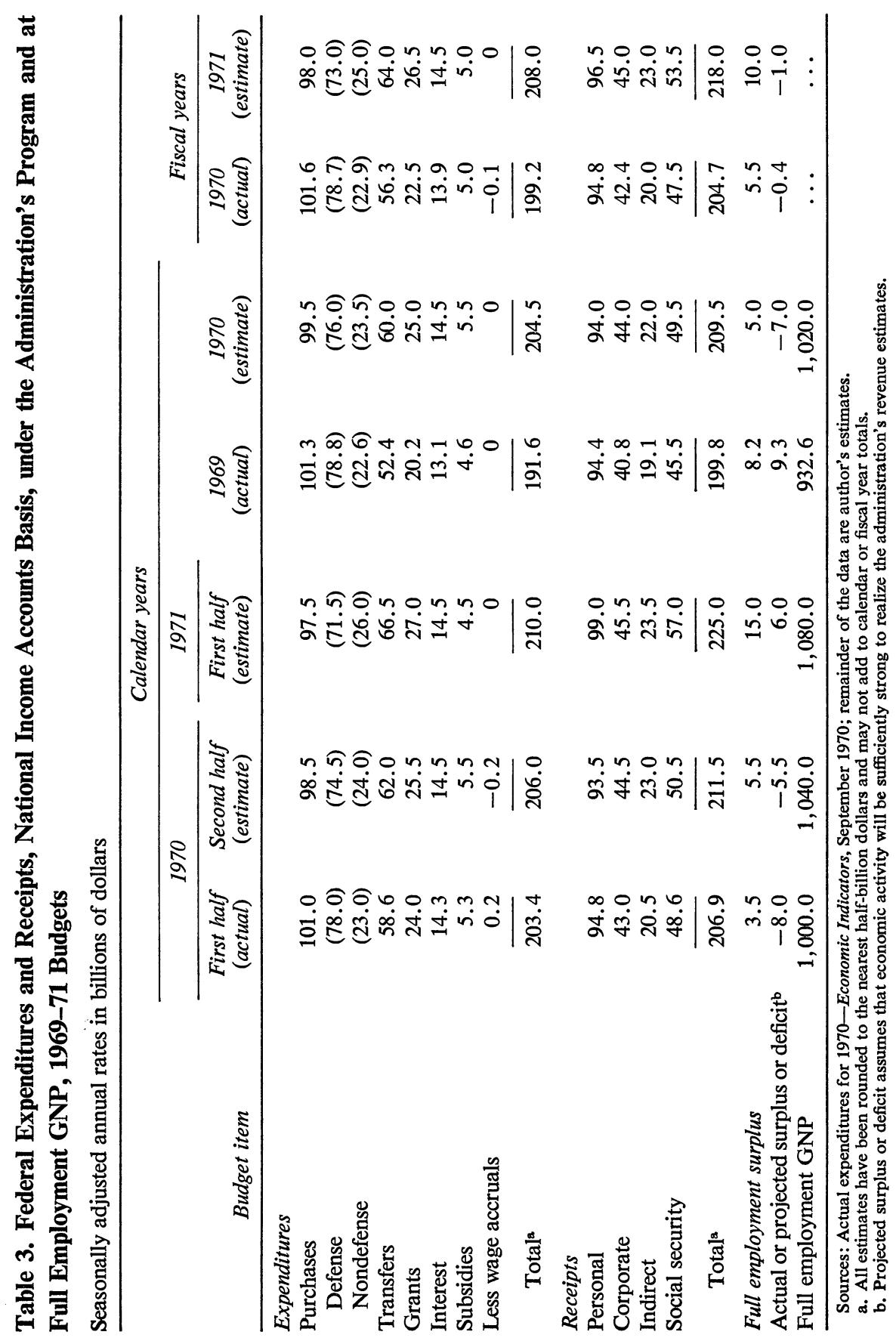


erately for the rest of the calendar year and return to a substantial surplus position in the first half of 1971 . The actual budget would remain in deficit for the rest of the calendar year, a continuing reflection of the significant shortfall of actual from potential GNP.

The deficit in calendar 1970 is primarily the result of the economic slowdown. Actual and potential GNP were approximately the same in calendar 1969. The difference between them has shifted from an excess of actual over potential of $\$ 4$ billion in the first half of calendar 1969 to a shortfall of actual from potential of nearly $\$ 35$ billion in the first half of 1970 . Even if federal revenues were merely proportional to GNP, that gap would account for $\$ 7$ billion of the shortfall in revenues. But, in fact, the impact on revenues is more than proportional. As is usual during an economic slowdown, corporate profits have fallen sharply, not only in current dollars but also as a share of GNP. Conversely, personal income, as a share of GNP, has risen. However, because of the differential tax rates, and because part of the sharp rise in personal income resulted from increased transfer payments, which are nontaxable, the shift in the distribution of income has resulted in an additional net loss in revenue of approximately $\$ 3$ billion (at annual rates) in the first half of 1970 . An additional $\$ 1$ billion, again at annual rates, of the first-half deficit can be accounted for by the rapid increase in unemployment benefit payments, which are not in full employment expenditures. For the fiscal year as a whole, if the economy had remained at full employment, the deficits of $\$ 0.4$ billion on the NIA basis and of $\$ 2.9$ billion on a unified basis would have been surpluses of $\$ 6.5$ billion and $\$ 4.0$ billion, respectively.

The expiration of the surcharge reduced available revenues sharply. Full employment revenues are estimated to increase by only $\$ 8$ billion between calendar 1969 and 1970, considerably less than half the normal growth associated with full employment GNP.

In his testimony before the Joint Economic Committee in July, the OMB director reported on the current status of the major appropriations bills. Some additional changes have occurred since July and these are incorporated into Table 4 . The estimates of congressional add-ons must be used with caution: Table 4 shows the estimates for increases in budget authority and outlays. As is readily apparent, not all of the increases in authority are translated into outlays in the same fiscal year. By September 23, Congress had enacted an additional $\$ 2.3$ billion in outlays, bringing total estimated expenditures to $\$ 209.2$ billion. 
Table 4. Status of Fiscal 1971 Budget Authority and Outlays, Unified Budget Basis, September 23, 1970

Millions of dollars

\begin{tabular}{|c|c|c|}
\hline \multirow{2}{*}{$\begin{array}{c}\text { Budget estimate, congressional action, } \\
\text { and program }\end{array}$} & \multicolumn{2}{|c|}{ Unified budget } \\
\hline & Authority & Outlays \\
\hline \multicolumn{3}{|l|}{ Total budget estimates } \\
\hline February 2,1970 & 218,030 & 200,771 \\
\hline May revisions & $\ldots$ & $+4,786$ \\
\hline July revisions & $+4,081^{\mathrm{a}}$ & $+1,297$ \\
\hline Total administration estimate & 222,111 & 206,854 \\
\hline \multicolumn{3}{|l|}{ Congressional add-ons } \\
\hline \multicolumn{3}{|l|}{ Enacted } \\
\hline Labor-HEW & $\ldots$ & +248 \\
\hline Education & +453 & +239 \\
\hline HUD and independent offices & +541 & -2 \\
\hline Emergency home financing & +750 & n.a. \\
\hline Unemployment trust fund & +194 & +50 \\
\hline Employees' health benefits & +121 & +121 \\
\hline Wage board pay raises ${ }^{b}$ & +230 & +230 \\
\hline Postal pay reform & +165 & +165 \\
\hline Savings bonds' interest increase & +100 & +100 \\
\hline Veterans' pensions and other benefits & +448 & +432 \\
\hline Postal rate increase & +784 & +784 \\
\hline \multirow[t]{2}{*}{ All other } & -585 & -49 \\
\hline & $+3,203$ & $+2,319$ \\
\hline Total enacted as of September 23,1970 & 225,314 & 209,173 \\
\hline \multicolumn{3}{|l|}{ Pending } \\
\hline \multicolumn{3}{|l|}{ Passed by House } \\
\hline Foreign assistance & -656 & -150 \\
\hline Agriculture & -82 & +106 \\
\hline Military construction & -138 & -11 \\
\hline TVA bonds & $+3,050$ & $\ldots$ \\
\hline Family assistance & -450 & -350 \\
\hline Other veterans' benefits & +187 & +182 \\
\hline Social security benefits & $\ldots$ & $+1,500$ \\
\hline Total & $\overline{+1,911}$ & $\overline{+1,282}$ \\
\hline \multicolumn{3}{|l|}{ Passed by Senate } \\
\hline Agriculture & +728 & +635 \\
\hline Housing Act of 1970 & +175 & n.a. \\
\hline Total & $\overline{+903}$ & +635 \\
\hline
\end{tabular}

Source: 1971 Budget Scorekeeping Report to the Joint Committee on Reduction of Federal Expenditures, 91 Cong. 2 sess. (1970), pp. 5-7. Figures are rounded and may not add to totals.

n.a. Not available.

a. Derived from May and July reestimates of outlays.

b. Awaiting presidential signature. 
Of the pending legislation, the social security bill, which passed the House resoundingly in May, would cause the largest probable increase in outlays. It provides a 5 percent across-the-board increase in benefits and other liberalizations (in addition to the 15 percent increase received earlier in the year) for a cost of $\$ 3.9$ billion at annual rates, to be effective January 1, 1971. About $\$ 1.5$ billion of this sum would be spent in fiscal 1971. The House version of the bill ties future increases in benefits to the consumer price index. If the index should rise by more than 3 percent after the last increase in benefits, benefits would be automatically increased the following January by the percentage of the increase in the index. The bill also automates increases in the wage ceiling to finance the higher benefit payments. The Senate, at the time of this review, had raised the across-the-board increase in benefits to 10 percent and had added at least one other expensive liberalization. The total cost of the social security amendments may exceed the $\$ 1.5$ billion estimated as the fiscal 1971 cost of the House bill.

One of the large increases in budget authority is the emergency home financing bill. Although estimates of outlays in fiscal 1971 are not available, the rate of spending under this bill could be substantial, depending on the state of the mortgage market during the year. Congressional action, therefore, may add between $\$ 2 \frac{1}{2}$ billion and $\$ 4$ billion to the totals implicit in the July testimony, raising the total to approximately $\$ 211$ billion.

There are a number of other contingencies that would increase expenditures and decrease revenues. The major contingency on the expenditure side is the passage of another military and civilian pay increase on January 1 instead of July 1, 1971. If the pay increase comes in January, it would add approximately $\$ 1.5$ billion to fiscal 1971 expenditures. The increased cost of a volunteer army would fall primarily into fiscal 1972, but if the proposal becomes law, it would add another \$250 million to fiscal 1971 expenditures. On the other hand, it does not appear that either revenue sharing ( $\$ 275$ million) or welfare reform ( $\$ 500$ million) will pass this year, saving $\$ 775$ million of originally proposed expenditures. Another possible expenditure reduction might result from congressional trimming of the administration's defense program. All in all, total expenditures could be another $\$ 1$ billion to $\$ 2$ billion higher than the $\$ 211$ billion, that is, in the range of $\$ 212$ billion to $\$ 213$ billion.

The last official revenue estimate was still based on a $\$ 985$ billion GNP and totaled $\$ 204.3$ billion. This revenue estimate would result in a deficit of about $\$ 8$ billion for fiscal 1971. However, included in the total revenue estimate is the revenue from the proposed tax on lead used in gasoline and 
the acceleration of the collection of estate and gift taxes. No congressional action has yet been taken on either of these proposals. An additional reduction of $\$ 200$ million to $\$ 300$ million may stem from the nonenactment of some of the requested user charges. Consequently, a deficit in the neighborhood of $\$ 11$ billion is a possibility, before any allowance is made for a somewhat weaker economy.

Table 5 shows the time phasing of the federal sector based on the higher estimate of total expenditures adjusted to full employment. The expenditure totals have been combined with full employment revenue estimates, assuming that neither of the proposed tax increases passes. The higher expenditure estimates and lower tax rates reduce the projected full employment surplus in the first half of 1971 sharply below the administration's program. There would nonetheless be only a slightly lower surplus in fiscal 1971 than in fiscal 1970.

If expenditures should be higher than the administration's July estimates, and if the drift away from potential GNP should continue, the actual budget could well be running sizable deficits throughout the fiscal year, in spite of the large increase in social security taxes scheduled to take effect on January 1, 1971. Much of the impact of expenditures above administration requests and the loss in revenues from proposed taxes that fail of enactment will be felt in the first half of 1971. Consequently, the difference between the deficit that would result under the administration's proposals and the deficit that would result if all possible contingencies come to pass is most marked in the second half of the fiscal year.

\section{A Look at 1972}

At this point in time, making any judgment, however tentative, about the budget for fiscal 1972 is bound to be hazardous. Most of the fiscal 1971 appropriations bills have not yet been passed, and virtually nothing is known about the administration's legislative program for the following years. Omitting discretionary increases or reductions, Table 6 displays the outlook for fiscal 1972.

If the economy were at full employment, approximately $\$ 10$ billion would be available for program expansion, tax reduction, or debt retirement. However, if the economy runs parallel to its potential, but the gap that is opening up is maintained during fiscal 1972, the normal growth in revenue could be expected but there would be no recoupment of the revenues lost this year. Under these circumstances, there could still be a deficit 


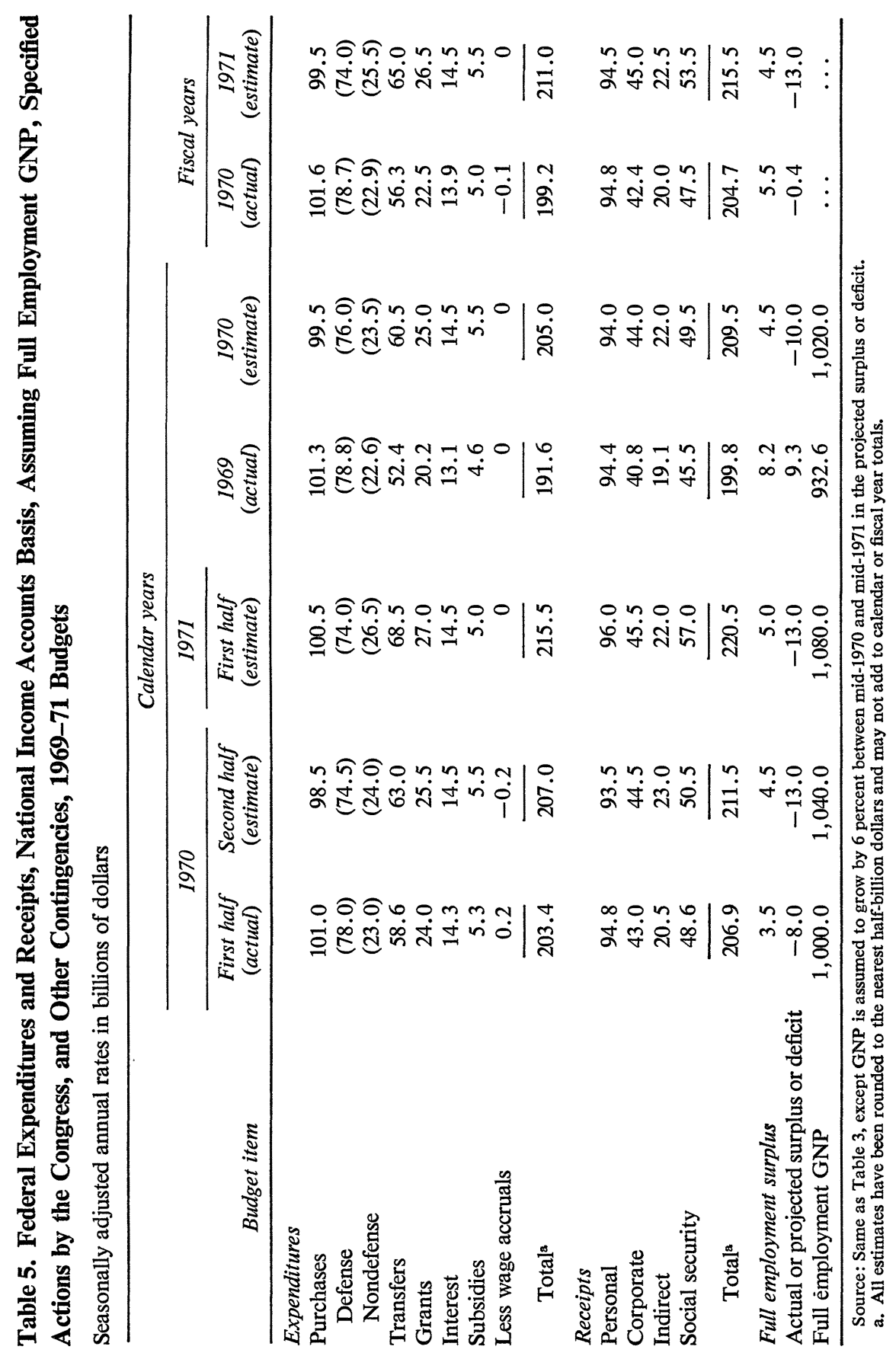


in 1972, even if fiscal policy were tightened markedly. The numbers are, of course, very tentative, and are in no sense a forecast of those that will appear in next January's budget document.

Table 6. Tentative Outlook for Fiscal 1972 Additions to Budget Outlays and Receipts, National Income Accounts Basis, Assuming Full Employment Economy

Billions of dollars

\begin{tabular}{|c|c|c|c|}
\hline Outlay or receipt & & Amount & \\
\hline \multicolumn{4}{|l|}{ Full employment budget } \\
\hline \multicolumn{4}{|l|}{ Outlays } \\
\hline Total, fiscal 1971 & 211.0 & & \\
\hline \multicolumn{4}{|l|}{ Increases, 1972 from 1971} \\
\hline Revenue sharing & & 1.1 & \\
\hline Family assistance & & * & \\
\hline \multicolumn{4}{|l|}{ Social security } \\
\hline Normal growth & & 1.5 & \\
\hline 1970 bill & & 2.4 & \\
\hline 1971 automatic growth ${ }^{\mathbf{a}}$ & & 1.0 & \\
\hline Pay increases & & 4.5 & \\
\hline All other built-in increases & & 1.5 & \\
\hline Total increases, 1972 from 1971 & & 12.0 & \\
\hline Total 1972 outlays & & & 223.0 \\
\hline \multicolumn{4}{|l|}{ Receipts } \\
\hline Total, fiscal 1971 & 215.0 & & \\
\hline \multicolumn{4}{|l|}{ Increases, 1972 from 1971} \\
\hline Social security & & 4.5 & \\
\hline Tax reform & & -3.0 & \\
\hline Normal growth & & 17.0 & \\
\hline User charges & & 0.5 & \\
\hline Surcharge expiration & & -1.0 & \\
\hline Total increases, 1972 from 1971 & & 18.0 & \\
\hline Total 1972 receipts & & & 233.0 \\
\hline \multicolumn{4}{|l|}{ Full employment surplus } \\
\hline Fiscal 1971 & 4.0 & & \\
\hline Fiscal 1972 & & & 10.0 \\
\hline \multicolumn{4}{|l|}{ Hypothetical actual budget, fiscal $1972^{b}$} \\
\hline Outlays & & 225.0 & \\
\hline Receipts & & 218.0 & \\
\hline Surplus or deficit & & -7.0 & \\
\hline
\end{tabular}

Source: Author's estimates.

* Less than $\$ 0.05$ billion. If the original proposal for family assistance were to pass, it would cost $\$ 4.4$ billion in its first full year of operation.

a. Assumes a 4 percent increase in the consumer price index.

b. Assumes lower GNP path during fiscal year 1971 and 4 percent real growth during fiscal year 1972 , and no new programs, cutbacks, or tax legislation. 